\title{
A DIGITÁLIS KOMPETENCIA ÉRTÉKELÉSI RENDSZERÉNEK EGYES KÉRDÉSEI
}

\section{SOME QUESTIONS OF THE DIGITAL COMPETENCE EVALUATION SYSTEM}

\author{
Nyikes Zoltán \\ Óbudai Egyetem, Biztonságtudományi Doktori Iskola, 1034 Magyarország \\ Budapest, Bécsi út. 96/b, nyikeszoli@gmail.com
}

\begin{abstract}
Digitalisation is part of our society structure. Development of the population digital knowledge is necessary because of the rapid technology innovation and its global presence. The digital competence level is identifiable by a standard evaluation system. On base of my researches I observed that nowadays doesn't found an evaluation system for the Hungarian global society. I'm working in my thesis on the supplement for this lack. I introduce it base on the European Union Digital Competence System and the digital intelligence definitions.
\end{abstract}

Keywords: digital competence, digital quality, digital competence framework, digital competence evaluation system, digital security \& safety, safety awareness

\section{Összefoglalás}

A mai társadalmi berendezkedésünk része a digitalizáció. A technológia rohamos fejlődése és annak az élet minden területét behálózó mivolta elengedhetetlenné teszi a lakosság digitális ismereteinek fejlesztését. Azonban, hogy a digitális ismeretek milyen szintüek, csak egy egységes mérési rendszer által beazonosítóak. Kutatásaim rámutattak arra, hogy jelenleg nincs a magyar össztársadalmi viszonyokra igazított és kidolgozott értékelési rendszer. Ezt a hiánypótlást kívánom megalkotni a következőkben. Az Európai Unió Digitális Kompetencia Keretrendszerének és a digitális intelligencia definícióinak felhasználásával, amelyet az alábbiakban mutatok be.

Kulcsszavak: digitális kompetencia, digitális intelligencia, digitális kompetencia keretrendszere, digitális kompetencia értékelési rendszere, digitális biztonság, biztonságtudatosság

\section{A digitális kompetencia értékelése}

A digitális kompetencia értékelési szintjeit azért fontos meghatározni, mert a felhasználó kap egyfajta értékelést a saját képességének szintjéről, valamint az értékelő személy vagy intézmény, például munkáltató, vagy pedagógus tudja azt, hogy az adott személy milyen szintü kompetenciával rendelkezik, valamint a kompetencián belül is az adott részterületen milyen a besorolása. Ugyanis az digitális kompetencia besorolása során az a cél, hogy azok a részterületek kerüljenek felszínre, amelyek elmaradnak a többitől. Emellett az is cél, hogy a képességek szintjének a meghatározásával a felhasználó, vagy az értékelő személy lássa azt az értékelés eredményéből, hogy mely területek erősítésével lehet a tudásszintet egységesíteni, 
illetve, melyek azok a képességek, amelyek fejlesztésére már nem kell erőforrást fordítani. [1]

\subsection{Előzmények}

A digitális kompetencia értékelési rendszerének kidolgozásához az Európai Unió Digitális Kompetencia Keretrendszerét használtam alapnak. Kutatásaim során megállapítást nyert, hogy a digitális kompetencia szintjeit és besorolását 2015ben az Európai Unió által, mintegy 120 fös nemzetközi szakértőkböl álló csoport elvégezte [2]. Ez a keretrendszer a munkavállalók és munkaadók hatékonyabb „egymásra találása” céljából készült. Ami, alapvetően a korszerü tudást igénylő munkaerőpiac szempontjából nagyon előnyös és valóban egy olyan értékelési rendszert sikerült alkotni a szakértöi csapatnak, amellyel a munkavállaló viszonylag jól megközelítő értékelést képes kapni a saját digitális kompetenciáját illetően. Azonban a megalkotott keretrendszer nem fedi le a társadalom azon teljes egészét, aki használja a digitális eszközöket és azon keresztül igénybe veszi a digitális javakat. Továbbá a keretrendszer véleményem szerint nagyon általános szempontokat foglal magába és ezáltal sajnos nem lehet például a kelet-európai és azon belül is a magyarországi társadalmat felmérni, mert a mi sajátosságainkra nincs benne értékelési szempont [3]. Gondolok itt, a nyugat-európaitól eltérő társadalmi értékrendre, a hazai fizetések és azok eloszlásának alakulására, a közszféra és a versenyszféra digitalizációjának helyzetére, a társadalmi és egyéni igényekre, a felhasználók egyéb más kompetencia képességeire, mint például az idegen nyelvismeret, a funkcionális szövegértés, továbbá az általános müveltségre, valamint a társadalmi ingerküszöbre és az arra ható tényezőkre, ezen felül a különböző társadalmi rétegek és korosztályok populációjára és összetételére.

\subsection{Aktualitás}

A fenti tényezők figyelembe vétele azért bír nagy fontossággal, mert a társadalmi rétegek és korosztályok között más igények és elvárások lépnek fel a digitális kompetenciát illetően. Szükséges felmérni azt a korosztályt, vagy felhasználói réteget, aki, mint ,,belépők” jelennek meg a digitális térben. Itt korosztály szerinti eltérés is lehet, mert egyszer ebbe a csoportba sorolhatók azok az óvodás korú gyermekek, akik már nagy érdeklődést mutatnak a digitális eszközök iránt, valamint ide sorolhatók azok a felnőtt korúak, akik ugyan használták már a digitális eszközöket, de az eddigiek során nem mutatkozott olyan igény, ami miatt ezt a képességüket fejleszteni kellett volna. De ide sorolhatók azok az időskorúak, akik úgy élték le az életüket, hogy eddig nem volt szükségük ilyen irányú képességek megszerzésére, de a modern felgyorsult világ és megváltozott életmód rákényszeríti arra őket is, hogy ezen ismereteiket és képességeiket fejlesszék. Mert sajnos a mondás, amely szerint: „Aki kimarad, az lemarad!” napjainkban hatványozottan értendő. A megváltozott életvitelünk, amely a technológiákra és azok fejlődésére épül, rákényszerít mindenkit arra, hogy a digitális kompetenciáját fejlessze. Ez nem minden esetben tudatosan történik, hanem az új technológiával való találkozást követően, annak alkalmazhatósága érdekében, a felhasználók kénytelenek elsajátítani azokat a szükséges ismereteket, amelyek annak müködtetéséhez szükségesek. A televíziózás, valamint a televízió készülékek hatalmas fejlődése lehet az egyik példa erre. Ezek a készülékek, mivel már digitálisak, olyan, a korábbiakban ismeretlen funkciókkal is rendelkeznek, amelyek használatához a felhasználónak el kellett sajátítania olyan új készségeket és fogalmakat, amelyeket korábban nem ismertek. A SMART, azaz okos televíziók, már az internet kapcsolat segítségével nem egy egyszerü televízió, 
hanem egy komplett multimédiás szórakoztató-, információs- és kommunikációs központ. Ez a technológiai fejlödés, hatalmas minőségszintbéli ugrást jelent azoknak az embereknek, akik évtizedekig a hagyományos katódsugárcsöves tévéket használták és most annak a régi technológiának az avulása okán kénytelenek ilyen új típusú eszközt vásárolni, viszont ezen eszközök használatához már nem elegendő a korábbi ismeret, megújítani, frissíteni szükséges azt [3].

\subsection{A szükségessége}

A televíziós evolúció drasztikusabban mutatja be azt a technológiai ,,sokkot”, ami éri a mai társadalmat, mint mondjuk a telefonok evolúciója. Ugyanis a telefonok esetében, amikor a 90-es évek közepétől elterjedtek a mobiltelefonok és szinte teljesen kiszorították a hagyományos vezetékes telefonokat, már ott új ismeretekre volt szüksége az átlag felhasználónak, viszont még az „csak” a telefonálásra és az ahhoz tartozó ismeretekre korlátozódott. Majd a 2000-es évek elején megjelentek az első adatmodemként is funkcionáló telefonok és a szolgálatatásban már adatforgalom is elérhető volt. Azonban ezek a telefonok még csak számítógéphez csatlakoztatottan tudtak internet elérést biztosítani. Majd a SMART telefonok hozták el az igazi áttörést a telefonon történő internet eléréssel. Az adatforgalom sebességének növekedésével és a tartalmak szerteágazó fejlődésével a telefonunk is már inkább egy hordozható komplett multimédiás szórakoztató-, információs- és kommunikációs központ. Viszont a felhasználónak, akik követték a technológiai evolúciót, mindig „kis dózisokban adagolva kapták" az új tudást. A telefon és a TV esete természetesen nem fedi le a digitális kompetencia szükségességét, mert ettől természetesen ez jóval szerteágazóbb és összetettebb kérdés. Ez a két kiragadott példa csak nagy vonalakban mutatja be azt, a problémát, aminek a felszámolása jelenleg is nagy társadalmi kihívás és kormányzati szándék, melyhez a felhasználók tudásszintjét felmérni szükséges bizonyos időközönként. [4]

1. táblázat. A digitális kompetencia értékelési szempontjai (készitette: a szerzö) [5]

\begin{tabular}{|c|c|}
\hline $\begin{array}{r}\text { Kompetencia } \\
\text { területek }\end{array}$ & Részkompetenciák \\
\hline 1. Információ & $\begin{array}{l}\text { 1.1 Böngészés, az információk keresése } \\
\text { és szürése } \\
1.2 \mathrm{Az} \text { információk kiértékelése } \\
1.3 \mathrm{Az} \text { információk tárolása és } \\
\text { visszakeresése }\end{array}$ \\
\hline \multirow[t]{6}{*}{ 2. Kommunikáció } & 2.1 A technológia hatása \\
\hline & 2.2 Az adatok tartalma és megosztása \\
\hline & 2.3 Részvétel az online társadalomban \\
\hline & 2.4 A digitális csatornák használata \\
\hline & 2.5 Netikett \\
\hline & 2.6 A digitális identitás kezelése \\
\hline 3. Tartalom & $\begin{array}{l}\text { 3.1 A tartalom fejlesztése } \\
\text { 3.2 A tartalmak integrációja és újbóli } \\
\text { felhasználása } \\
\text { 3.3 Szerzői jogok és engedélyek } \\
\text { 3.4 Programozási ismeretek }\end{array}$ \\
\hline \multirow[t]{2}{*}{ 4. Biztonság } & 4.1 Védelmi eszközök \\
\hline & $\begin{array}{l}\text { 4.2 A személyes adat és a digitális } \\
\text { identitás védelme } \\
\text { 4. A biztonságtudatosság }\end{array}$ \\
\hline $\begin{array}{l}\text { 5. Probléma- } \\
\text { megoldás }\end{array}$ & $\begin{array}{l}\text { 5.1 Müszaki problémák megoldása } \\
\text { 5.2 A felhasználói igények és azok } \\
\text { technológiai megoldásainak azonosítása } \\
5.3 \text { A digitális eszközök használatával } \\
\text { kapcsolatos fejlesztések, újitások, } \\
\text { megoldások } \\
\text { 5.4 A digitális kompetencia } \\
\text { hiányosságainak azonosítása }\end{array}$ \\
\hline 6. Tudásátadás & $\begin{array}{l}\text { 6.1 A felhalmozott tapasztalatok átadása } \\
6.2 \text { Az elsajátított ismeretek átadása } \\
6.3 \text { Saját példán, viselkedésen keresztül } \\
\text { történő tudásátadás }\end{array}$ \\
\hline
\end{tabular}

\section{Digitális alapkészségek}

A Yuhyun Park [6] szerint 8 (7) fontos digitális alapkészség létezik. Ezek: digitális irástudás, digitális kommunikáció, digitális érzelmi érettség és intelligencia, digitális biztonság (elkülönítve ,, security” és , safety”, ágazatokra, előbbibe a ,hagyományos” kibervédelmet sorolják, a másikba pedig a 
digitális kapcsolattartással, tartalommal kapcsolatos kockázatok kivédését). Továbbá a digitális jogok ismerete, a digitális „egyéniségünk” (digitális állampolgár, vállalkozó és alkotó), a digitális használat („use” alá sorolják a digitális egészségügyet, közösségi tevékenységet és a képernyő előtti egyéb tevékenységeket). A probléma abban rejlik, hogy a digitális világ gyorsan és folyamatosan változik, ahol a kormányzati szintü gyermekvédelmi politika lassan zárkózik fel az internet veszélyeinek a kivédésére, illetve a káros hatásainak tompítására [7].

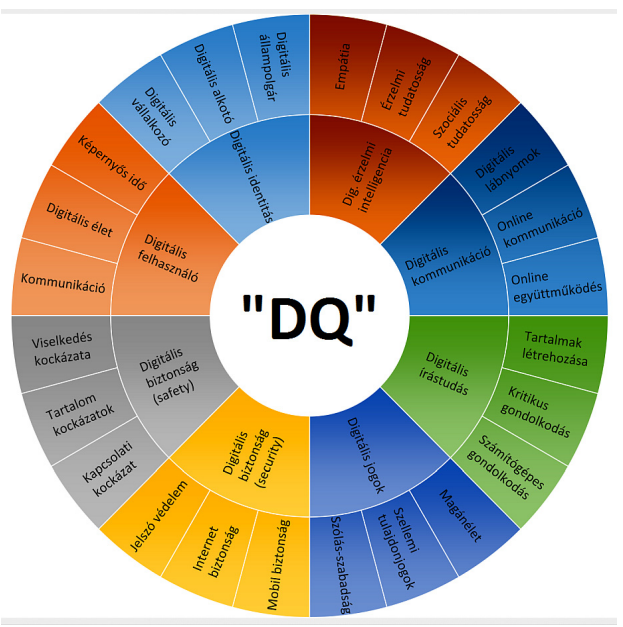

1. ábra. A digitális intelligencia „DQ” alkotóelemei (készitette: a szerzö) [6]

\section{Következtetések}

$\mathrm{Az}$ Európai Unió által kidolgozott keretrendszer és a digitális intelligenciában megfogalmazottak alapján kidolgozom a magyar sajátosságokat is figyelembe vevő digitális kompetencia értékelési rendszerét. A magyar társadalom sajátosságait figyelembe vevő digitális kompetencia értékelési rendszer kidolgozásának elsődleges célja, hogy segítse a hazai gazdasági jólét szintjének emelését, annak fejlődését és a társadalom nyugati színvonalra történő mielőbbi felzárkózását. Továbbá biztosítsa a társadalom tagjainak a biztonságtudatossági szint növelését, amely a mindenki számára újdonság erejével ható kiberteret jellemzi.

\section{Szakirodalmi hivatkozások}

[1] Lazányi Kornélia: Stressed Out by the Information and Communication Technologies of the 21st Century, SCIENCE JOURNAL OF BUSINESS AND MANAGEMENT 4:(1-1) pp. 10-14. 2016, http://article.sciencepublishinggroup.com/pdf/1 0.11648.j.sjbm.s.2016040101.12.pdf, letöltve: 2017. február 6.

[2] A common European Digital Competence Framework for Citizens. Europen Commision, Europen Union, 2016, https://www.openeducationeuropa.eu/sites/defa ult/files/DIGCOMP\%20brochure $\% 202014 \% 20$ .pdf, letöltve: 2017. január 20.

[3] Gutiérrez Porlán, J. \& Serrano Sánchez. J.L. Evaluation and development of digital competence in future primary school teachers at the University of Murcia. Journal of New Approaches in Educational Research, 5(1), 5156. doi: $10.7821 /$ naer.2016.1.152 https://naerjournal.ua.es/article/view/v5n18?platform=hootsuite letöltve: 2017 . február 6 .

[4] Measuring Digital Skills across the EU: EU wide indicators of Digital Competence. 2014, https://ec.europa.eu/digital-singlemarket/en/news/measuring-digital-skillsacross-eu-eu-wide-indicators-digitalcompetence letöltve: 2017 . február 5.

[5] Digital competences - Self-assessment grid. European Union, 2015 http://europass.cedefop.europa.eu/sites/default/ files/dc-en.pdf, letöltve: 2017. január 20.

[6] Yuhyun Park: 8 digital life skills all children need - and a plan for teaching them. World Economic Forum, Global Agenda, 2016, https://www.weforum.org/agenda/2016/09/8digital-life-skills-all-children-need-and-a-planfor-teaching-them, letöltve: 2017. január 29.

[7] Anusca Ferrari: Digital Competence in Practice: An Analysis of Frameworks EUR Scientific and Technical Research series, Luxembourg, 2012, ISBN 978-92-79-25093-4 doi:10.2791/82116, https://naerjournal.ua.es/article/viewFile/v5n18/196, letöltve: 2017. január 30. 